\title{
Fen Bilgisi Öğretmen Adaylarının Zaman Yönetimi Becerileri Düzeylerinin Belirlenmesi
}

\author{
*1 Kevser ARSLAN ve ${ }^{2}$ Ünsal UMDU TOPSAKAL \\ *11Fen Bilimleri Enstitüsü Yıldız Teknik Üniversitesi, Türkiye \\ ${ }^{2}$ Eğitim Fakültesi, Matematik ve Fen Bilimleri Eğitimi Bölümü, Yıldız Teknik Üniversitesi, Türkiye
}

\section{Özet}

Etkili ve verimli zaman yönetimi, öğretmenler açısından eğitim sürecinde büyük öneme sahip bir yönetim alanıdır. $\mathrm{Bu}$ doğrultuda öğretmen adaylarının etkili ve verimli zaman yönetimi konusunda yeterli becerilere sahip olması gerektiği söylenebilir. Özellikle bu yeterlilik fen bilimleri dersi kapsamında kendini ön plana çıkarmakla birlikte Fen Bilimleri Öğretmenleri tarafından zaman etkili ve verimli yönetilmelidir. Bu araştırmanın amacı, fen bilimleri öğretmen adaylarının zaman yönetimi becerilerini ortaya koymak ve beceri düzeylerinin sınıf kademesine göre değişimini belirlemektir. $\mathrm{Bu}$ amaç doğrultusunda 2018-2019 öğretim yılında İstanbul'da bir devlet üniversitesinde öğrenim görmekte olan toplam 135 fen bilimleri öğretmen adayı amaçsal örneklem yoluyla seçilmiştir. Veri toplama aracı olarak Zaman Yönetimi Ölçeği uygulanılarak elde edilen veriler SPSS istatistik programı ile analiz edilmiştir. Verilerin analizinde ortalama, standart sapma ve tek yönlü varyans analizlerinden yararlanılmıştır ve sonuçları değerlendirilmiştir. Fen bilimleri öğretmen adaylarının zaman yönetimi becerileri ile sınıf düzeylerinin arasında anlamlı bir farkın olmadığı ve zaman yönetimi becerileri puanlarının "yüksek" düzeyde olduğu belirlenmiştir.

Anahtar Kelimeler: Fen Bilgisi Öğretmen Adayları, Zaman Yönetimi Becerisi

\begin{abstract}
Effective and efficient time management is an area of management that is of great importance for teachers in the education process. In this respect, it can be said that teacher candidates should have sufficient skills in effective and efficient time management. In particular, this competence should be managed effectively and efficiently by science teachers, although it is important to emphasize itself in the context of the science course. The aim of this study is to determine the time management skills of science teacher candidates and to determine the change in skill levels according to the level of class. In line with this aim, a total of 135 science teacher candidates who have been studying at a State University in Istanbul in 2018-2019 academic year were selected through objective sampling. The data obtained by using Time Management scale as the data collection tool were analyzed by SPSS statistical program. The mean, standard deviation and one-way variance analyses were used in the analysis of the data and the results were evaluated. It was determined that there was no significant difference between time management skills and classroom level of science teacher candidates and time management skills were "high".
\end{abstract}

Keywords: Science Teachers Candidates, Time Management Skills

\section{Giriş}

Sözcük anlamı olarak zaman, olayların geçmişten günümüze gelip, geleceğe doğru birbirini takip ettiği, bireyin kontrolü dışında aralıksız devam eden bir süreçtir[1].Başka bir deyişle zaman belirli bir işi gerçekleştirebilmek için ihtiyaç duyulan süredir [2].TDK'nin sözlüğünde ise zaman kavramı "Bir işin, bir oluşun içinde geçtiği, geçeceği veya geçmekte

*Kevser ARSLAN: Address: Eğitim Fakültesi, Fen Bilgisi Eğitimi, Yıldız Teknik Üniversitesi, İstanbul Türkiye. Email address: arslankevser96@gmail.com, Doi: 10.33793/acperpro.02.01.13 
olduğu süre, vakit." biçimi ifadesiyle tanımlanmıştır[3].Zaman yönetimi, fertlerin hususi ve iş yaşantısında belirlemiş olduğu hedeflere etkili ve verimli bir biçimde ulaşabilmesi için planlama, düzenleme ve kontrol gibi yönetsel fonksiyonları kendi etkinlikleri üzerine uygulayabilme sürecidir[4].Başka bir ifadeyle zaman yönetimi, zamanın etkili kullanımı anlamını taşımaktadır. Zaman herkese eşit dağıtılmış kıt kaynak olmasıyla başta olmak üzere zaman biriktirilememesi ve çoğu mallardaki tutumluluk ile zamandaki tutumluluk değişiklik göstermesi gibi kendine özgün birçok yönleri de mevcuttur. Sınıf yönetimi açısından zaman her öğretmene 45 'er dakikalık dilimler şeklinde eşit dağıtılması sebebiyle öğretmene düşen, bu zaman dilimini amacına uygun ve verimli kullanmaktır. Sınıf yönetimi bakımından zamanın her diliminin işlevi, rolü ve önemi dikkate alınarak yapılmış bir plan doğrultusunda çalışılmalıdır ve sınıf yönetimi açısından işleri ertelemeden, geciktirmeden plan dâhilinde yaparak gerçekleştirilmelidir. Zaman ölçülebilirliği yönüyle öznel ve nesnel zaman şekliyle gruplandırılmaktadır. Sınıf yönetiminin büyük bir bölümünde nesnel zamandan bahsedilir[5].Bir öğretmenin okul saati gibi belirli zaman dilimleri düzene sokulmuştur. Okul zamanında gelmek, derse girmek ve dersi anlatması gibi belirli bir zaman içinde yerine getirilmesi gereken görev ve etkinlikler öncelik sırasına sahiptir. $\mathrm{Bu}$ açıdan bakıldığında zaman belirli görevler ya da ödevler tarafından kontrol edilir.

Zaman yönetimi yaklaşımları alanlarına göre farklı şekillerde sınıflandırılarak 8 başlık altında toplanmıştır[2,6,7]. Bu başlıklar altında bir öğretmen açısından sınıf yönetiminde bu yaklaşımlardan nasıl ve ne derece yararlanacağının değerlendirmesi gereklidir. Düzen Yaklaşımı çerçevesinde zamanın doğru kullanımını sağlamak adına nesne, görev ve işgörenler olmak üzere üç temel düzenleme üzerinde yoğunlaşmak gerekir[6].Düzen yaklaşımının sınıf yönetimine yansıması, sınıfın doğru bir şekilde fiziksel olarak düzenlenmesi, çalışmaların etkin planlanması ve bazı işleri doğru yapabilecek öğrencilerin görevlendirilmesinin gerçekleştirilmesiyle olacaktır. Zamana Sahip Çıkma Yaklaşımına göre zamanının etkin kullanılması için kendini izole etmek, yalnız kalmak ve yetki devretmek tavsiye edilir[6].Farklı iş ve kişilere yönelmek yerine hedefe yönelik çalışmak gerekir. Bu yaklaşım önderliğinde sınıf içerisinde öğretmen öğrencilere bazı işler verilerek, yaptırılarak zaman yönetimini gerçekleştirilir. Başarı(Hedef) Yaklaşımı, doğrultusunda amaçların tam anlamıyla ortaya koyup neyi nasıl yapmak istediğini bilen bireylerin zamanı etkin kullanabileceğini savunulur. Eğitim süreci de özünde amaçlar ve planlar çerçevesinde oluşturulan etkinliklerdir. Bu yüzden bu yaklaşımın eğitim ve sınıf yönetimine uygulanması oldukça kolaydır. Özellikle kısa vadeli hedefler konularak zamanla bu hedeflere ne derece ulaşılmış olduğunu ölçerek zamanının etkin kullanımı sınanılabilir. ABC Yaklaşımına göreyse işlerde öncelik sıralaması yapılır. A grubuna dâhil edilen işler önemli ve ertelenmeyecek işler, B grubuna dâhil edilen işler orta derecede önemli işler ve $\mathrm{C}$ grubundakiler ise sona bırakılabilen, yapılamaması halinde problem çıkarmayacak olan işlerdir[6].Bu yaklaşım temel alınarak sınıf yönetiminde bu şekilde bir gruplama yapılarak bazı işler ertelenebilir veya öğrencilere devredilir. Covey'in Zaman Yönetimi Yaklaşımına göre ise zamanın etkili kullanılması, önceliklerin ve önemliliklerinin tercih edilmesi ve sıralamasına bağlıdır[7].Bu yaklaşım, sınıf yönetiminde öncelik ve öneme göre işlerin sınıflaması gereken etkinlikler için kılavuz olmaktadır. Teknoloji(Sihirli Araç)Yaklaşımında verimli bir zaman yönetimi için doğru araç ve gereçlerin kullanılması savunulur. Takvim, ajanda, bilgisayar gibi araç ve gereçlerin akılcı kullanımını temel alır. Sınıf yönetimi kapsamında çeşitli ders araç ve gereçleri ile çağdaş iletişim ve bilişim sistemlerinin kullanılmasıyla bu yaklaşım gerçekleştirilir. Beceri Yaklaşımında bireylerin kimi becerileri sahip olması ile zamanın verimli olabileceğini savunulur. $\mathrm{Bu}$ yetenekler; doğru karar verme, amaç belirleme, planlı iş yapma, öncelikleri sıralama, akılcı yetki 
devridir[1].Bu yaklaşım sınıf yönetiminde faydacı hedef belirlenerek, planlı davranışlar sergilenilerek, amaçlara doğrultusunda öğretme-öğrenme süreci uygulanır ve öğrencilere yetki devredilerek uygulanabilmektedir[8].İyileştirme Yaklaşımı ise zamanın amaçsız kullanımı, sosyo-psikolojik çevre etkenlerine bağlıdır. Bu kapsamda sınıf yönetiminde öğrencilerde zaman yönetimi bilini oluşturmak ve mükemmeliyetçi yapıya yok etme ve buna karşı yöntem geliştirme çalışmaları uygulanabilir.

Zaman, her meslek kümesinde yer alan bireyler üzerinde baskı oluşturmuş evrensel bir kaynaktır. Ancak öğretmenlik mesleği adına zaman yönetimi daha büyük bir önem arz etmektedir. Öğretmenlik, planlı çalışmaya ve zamanın iyi yönetilebilmesine dayanan bir meslektir. Zaman yönetimi ilkelerinin bilinmesi öğretmenlerin ve öğretmen adaylarının ortaya koydukları amaçlara daha az zaman kaybıyla ulaşılmasını sağlayacaktır. Buna rağmen eğitim programlarının uygulanabilmesi için okullara verilmiş olan süre kısıtlıdır. Bu sebepten dolayı öğretmenlerin en çok yakındıkları konulardan biri bu süre zarfında eğitim programını yetiştirmek zorunluluğu içerisinde olmalarıdır. Tüm branşlardaki öğretmenler ve adayları kendilerini devamlı saat ve takvimin baskısı altında hissederler. Üstelik okul ve sınıf ortamında değerli olan zamanın kaybetmesine sebep olan birçok etken söz konusu olmasına rağmen; konuları belirtilen tarih ve vakitte anlatabilmesi gerekmektedir. Özellikle diğer tüm branşlara nazaran fen bilimleri öğretmenlerinin zaman yönetimi becerisine sahip olması daha büyük önem arz etmektedir. Fen bilimleri dersinin içeriği yalnızca formüller, işlemler ve problemler oluşturmaz ve doğrudan anlatım yapılarak etkili bir fen eğitiminin tam anlamıyla gerçekleştirilmesi mümkün değildir. Fen bilimleri dersi programı içerisindeki mevcut konuların çoğunda soyut kavramlar (elektriklenme, atom, fotosentez, solunum vb.) bulunmaktadir. Yer alan kavramlar soyut olmasi sebebiyle, öğrenmede zorluklar yaşanmaktadır[9].Bu kavramların öğrenciye doğrudan anlatım yapılması pek doğru olmayacaktır. Bu nedenle öğretmen bu kavramları öğrenci zihninde somutlaştırmak için ayrıca bir zaman harcar. Fen bilimleri öğretmeni yeni bir konuya giriş yapacağı zaman öncelikle öğrencinin zihinlerinde yapılanmış olan geçmiş bilgilerini ve konuya dair kavramları belirler ve sonraki aşamada yeni bir bilgiyi aktarır. Yine bu durumda zaman yönetimi açısından bir eksiklik oluşturur. Fen Bilimleri öğretim programlarının hedefine ulaştırılabilmesi için öğretmenlerin ve adaylarının eğitim süreci içerisinde materyal kullanmalıdır."Eğitimde materyal kullanımı, kavrama ve öğrenme işlemlerine kolaylık sağlar. İlgi uyandırır, sınıfa hareketlilik kazandırır. Öğrenmede, zamanı kısaltır, bilginin pekiştirilmesini ve kalıcılığının sağlanmasında rol oynar.[10]Bu materyalin öğretmen ve öğrenci tarafindan oluşturulma ve kullanma süreci daha fazla zamana ihtiyaç duyulması gerektiğine işaret eder. Fen bilimleri dersinde laboratuar kullanımı, feni diğer alan derslerinden farklı kılar. Laboratuar kullanımı fen bilimleri eğitiminde kilit noktadır. Öğrencilere ne öğretileceğinden ziyade, nasıl öğretilmesi gerektiğine odaklanılmaktadır. Özellikle fen bilimlerindeki herhangi bir konu laboratuar ortamında deney yapılmasa öğrenci için soyut kalacaktır. Fen eğitiminde çoğu konu deney ve gözlem gerektirir. Öğretmen ise bu laboratuar ortamlarını kullanması için etkin bir planlama yapabilmelidir ve zamanı etkin kullanabilmelidir. Fen öğrenimi; yaparak yaşayarak ve görerek gerçekleştirilir. Öğretmen, öğrencilere ders kapsamında konuya uygun olan bir okul dışı öğrenme ortamı olan, tabiat park1, müze, akvaryum gibi mekânlara gezi düzenleme ihtiyacı duyabilir. Canlandırmalar, öğrencilerin ilgilerini konuya yöneltme ve çalışmaya güdülemede son derece başarılıdır[11].Bu nedenle bir fen eğitimcisi konuların anlaşılmasını sağlamak adına öğrencilere işleyeceği konuya yönelik bir drama etkinliği yaptırarak canlandırma yapabilir. Diğer bir taraftan Fen öğretimini gerçekleştiren öğretmenin derslerinde, konuların niteliğini bağlı olarak öğretim stratejileri, 
yöntem ve tekniklerini etkin olarak kullanması gerekir. Tüm bunların gerçekleştirilebilmesi zaman yönetim becerisine sahip olunması gerekliliğine işaret eder.

Özetle, fen dersi kapsamında öğrencilere hazır bilgilerin doğrudan verilmesi engellenmeli ve bilgiye ulaşabilme yeteneğini edinmelerinin sağlanması gerekir. Bu doğrultuda, bilişsel duyuşsal ve devinişsel davranışlarının kazandırılabilmesi amacıyla deneyler, oyunlar, analojiler, kavram haritaları, bilgisayar destekli öğretim gibi çeşitli öğretim ortamları oluşturularak işbirliğine dayalı ders işlenmesi gerekir. Tüm bunlar fen bilimleri öğretmen ve adaylarının etkili ve verimli ders saati oluşturabilmeleri için yeterli düzeyde zaman yönetimi becerisine sahip olması gerektiğini vurgular. Fen bilimleri öğretmeni, etkili bir fen eğitimi gerçekleştirebilmesi için zamanı çok iyi kullanabilmeli, uygun bir plan oluşturabilmeli ve mevcut zamanını hem öğrenci açısından hem de kendi açısından etkin hale getirebilmelidir.

Literatürü incelediğimizde, zaman yönetimi konusunda birçok araştırma gerçekleştirilmiştir. Bir çalışmada ilkokul yöneticilerinin zamanı ne düzeyde etkin kullandıkları belirlemesi amaçlanırken[12];başka bir çalışmada ortaöğretim kurumlarında görev yapan yöneticilerin zaman yönetimi becerilerinin belirlemesi amaçlanmıştır[13].Öğrencilere yönelik gerçekleştirilmiş olan çalışmalarda hazırlık okulu öğrencilerinin zaman yönetimi becerileri ve stres yönetimi becerileri arasındaki ilişini belirlenirken[14];19 Mayıs Üniversitesi (OMÜ) ve Azerbaycan Devlet İktisat Üniversitesi (ADï̈) lisansüstü öğrencilerinin zaman yönetimi becerileri kişisel demografik bilgilere göre incelenmiştir[15].Bununla birlikte alan yazında yapılan çalışmalarda Fen Bilimleri eğitimcilerine yönelik zaman yönetimi becerisi kapsamında çalışmalarının eksik olduğu söylenebilir. Bu bağlamda zaman yönetiminin fen eğitimcileri açısından önemi düşünüldüğünde, bu konuda yapılan çalışmaların alan yazısı yönünden gerekli olacağı açıktır. Dolayısıyla yapılan çalışma Fen Bilgisi öğretmen adaylarının sahip olduğu zaman yönetimi becerilerinin ortaya çıkarılmasını ve cinsiyet ile ilişkisinin belirlenmesini amaçlamaktadır.

\section{Yöntem}

\subsection{Araştırma Modeli}

Gerçekleştirilmiş olan araştırma nicel bir çalışma olup, araştırmada fen bilgisi öğretmen adaylarının zaman yönetimi becerilerini ortaya koymak ve beceri düzeylerinin sınıf kademesine göre değişimini incelenmek amaçlanmıştır.Araştırmada genel tarama modellerinde biri olan betimsel tarama modeli kullanılmıştır.Tarama modeli katılımcıların görüşlerinin ya da ilgi, beceri, yetenek ve tutum gibi özelliklerinin belirlendiği bir modeldir[16].Geçmişte ya da halen var olan durumun var olduğu şekliyle betimlendiği bu yöntemde önemli olan, araştırmaya konu olan olayı, bireyi ya da nesneyi kendi koşulları içinde olduğu gibi tanımlayabilmek ve mevcut durumu değiştirmeye kalkmadan gözleyebilmektir [17].

\section{2.Çalışma Grubu}

Araştırmanın çalışma grubunu 2018-2019 eğitim öğretim y1lında İstanbul'da bir devlet üniversitesinde öğrenim görmekte olan fen bilgisi öğretmen adayları oluşturmaktadır. Örneklemin belirlenmesinde kolay ulaşılabilir durum örneklemesine başvurulmuştur. Kolay ulaşılabilir durum örneklenmesinde, örneklem araştırmacının çalışmasını yürütmesi için uygun özelliktedir ve bu örnekleme ulaşmak kolaydır. Örneklem rastgele ya da sistematik olarak seçilemediği durumlarda tercih edilebilir[18].

Çalışmanın örneklemini, 39 birinci sınıf, 31 ikinci sınıf, 25 üçüncü sınıf ve 40 dördüncü sınıf olmak üzere toplamda 135 öğretmen adayı oluşturmaktadır. Çalışmaya katılan 135 öğretmen adayının 114'ü kız öğrenci ve 21'i erkek öğrencidir. 


\subsection{Veri Toplama Aracı}

Araştırmada nicel veriler kullanılmıştır. Veri toplama aracı olarak öğrencilerin zaman yönetimi becerilerini belirlemek amaçlı Zaman Yönetimi Envanteri (ZYE) ve kullanılmıştır. ZYE Britton ve Tesser (1991) tarafindan geliştirilmiş, Türkiye'ye uyarlaması Alay ve Koçak (2002) tarafından yapılmıştır[19,20].Anket formunda, 5'li likert ölçeği (hiç, nadiren, bazen, sık sık, her zaman) şeklindedir. Ölçek "Zaman Planlaması" "Zaman Tutumları" ve "Zaman Harcattırıcılar" faktörlerinden oluşup, her faktörde sirasıyla 16,7 ve 4 ifade olmak üzere toplam 27 ifade bulunmaktadır. Anketin geçerliği iç-geçerlik ve yapısal geçerlik ile belirlenmiştir. Anketin güvenirliği 0.87 olarak bulunmuştur.

\subsection{Veri Toplama Aşaması}

Zaman Yönetimi Envanteri çalı̧̧maya katılan gönüllü öğretmen adaylarına sınıf ortamında uygulanmıştır. Gerekli açıklamalar yapıldıktan sonra öğrencilere cevaplamaları için yeterli zaman verilmiştir. Uygulama aşamasında katılımcılara hiçbir müdahale yapılmamıştır.

\subsection{Veri Analizi}

Fen bilgisi öğretmen adaylarının zaman yönetimi envanterine verdikleri yanıtlar analiz edilmek üzere SPSS istatistik programına aktarılmışır. SPSS istatistik programında öğrencilerin zaman yönetimi becerileri puanları belirlenmiş ve zaman yönetimi toplam puanlarının bulundukları sınıf seviyesine göre farklılık gösterip göstermediğinin belirlenmesi için ise tek yönlü varyans analizi ANOVA yapılmıştır. Öğrencilerin zaman yönetimi anketinde ortaya çıkan üç alt faktör puanlarının ve zaman yönetimi toplam puanlarının bulundukları sınıfa göre elde ettikleri puanları betimlemek için ortalamalar ve standart sapmalar kullanılmıştır.

\section{Bulgular}

Fen bilgisi öğretmen adaylarının zaman yönetimi becerilerinin sınıf düzeyleriyle olan ilişkisinin belirlenmesine yönelik gerçekleștirilen araştırmada, öğretmen adaylarının zaman yönetimi ölçeğine vermiş oldukları yanıtların ortalamaları tek yönlü varyans analizi (ANOVA)yardımıyla karşılaştırılmış ve adayların zaman yönetim puanları sınıf düzeyleri doğrultusunda ortalamaları, standart sapmaları betimsel analiz edilerek yorumlanmıştır. Verilerden elde edilen bulgular aşağıda tablolar halinde verilmektedir.

Tablo 1. Fen Bilimleri Öğretmen Adaylarının Zaman Yönetimi Becerileri Puanlarının Öğrenim Gördükleri Sınıflar Değișkenine Göre ANOVA Sonuçları

\begin{tabular}{cccccc}
\hline Varyansın Kaynağı & Kareler Toplamı & Sd & Kareler Ortalaması & $\mathrm{F}$ & $\mathrm{P}$ \\
\hline Gruplar arası & 1030.192 & 3 & 343.397 & 2.213 & 0.90 \\
Gruplar içi & 20325.542 & 131 & 155.157 & & \\
\hline Toplam & 21355.733 & 134 & & & \\
\hline
\end{tabular}

Fen Bilgisi Öğretmenliği öğrencilerinin sınıf düzeylerine göre zaman yönetimi puanları arasında anlamlı farklılık olup olmadığını belirlemek için ANOVA testi seçilmiştir. ANOVA'nın varsayımları sinanmıştır. Veriler normal dağılım göstermektedir ve Levene F testine göre varyanslar homojendir. Tablo 1'de görüldüğü gibi, fen bilimleri öğretmen adaylarının farklı sınıf düzeyindeki zaman yönetimi beceri düzeyleri arasındaki analiz sonuçları değerlendirildiğinde öğrencilerin sahip olduğu zaman yönetimi becerileri arasında sınıf düzeyleri bakımından anlamlı bir fark olmadığını görülmektedir. $\mathrm{F}(3,131)=2.213$, $\mathrm{p}>0.05$. Buradan, sınıflar bazında, tüm fen bilimleri öğretmen adaylarının zaman yönetimi beceri düzeylerinin benzer olduğu sonucuna var1labilir. 
Tablo 2. Öğretmen Adaylarının Sınıf Düzeylerine Göre Zaman Yönetimi Puan Değerleri

\begin{tabular}{ccl}
\hline SINIF & $\mathbf{N}$ & Alpha $=\mathbf{0 . 0 5}$ \\
\cline { 3 - 3 } DÜZEYLERI & & ZAMAN YÖNETIM PUAN DEĞERLERI \\
1.SINIF & 39 & 81,2051 \\
2.SINIF & 31 & 87,0323 \\
3.SINIF & 25 & 84,6800 \\
4.SINIF & 40 & 87,9250 \\
\hline
\end{tabular}

Tablo 2'den anlaşılacağ1 üzere; Fen bilimleri öğretmen adaylarının öğrenim gördükleri sınıf düzeyi değişkenine göre zaman yönetim beceri puanları kıyaslandığında dördüncü sınıf öğrencilerinin yönetim becerileri diğer sinıflara göre daha yüksek düzeyde olduğu görülür. En düşük zaman beceri puanına ise birinci sınıfların sahip olduğu görülmektedir. Ancak burada ilgi çekici olan ikinci sınıf öğrencilerinin zaman yönetim puanlarının dördüncü sınıf öğrencileri ile aynı düzeyde olduğu ve diğer üst sınıf kademesinden daha yüksek olduğu göze çarpmaktadır. $\mathrm{Bu}$ durum dışında sınıf düzeyleriyle artış göstermesiyle birlikte zaman becerilerinin artış göstermiş olduğu söylenebilir. Birinci sınıf öğrencilerinin düşük çıkmasının nedeni olarak öğrencilerin yeni bir bağlam ve sistem içerisine girmeleri sebebiyle uyum aşamasında olmaları dolayısıyla da geçmişteki sistem durumunu ve alışkanlıklarını sürdürmeye devam etmeleri gösterilebilir. $\mathrm{Bu}$ durumun bir tesiri olarak da üniversite yıllarını öğrencilerin pek çok açıdan önemli değişimler geçirdikleri bir geçiş dönemi olarak düşünürsek özellikle önceki eğitim dönemlerine oranla daha ileri bir eğitim ve öğrenim görülen üniversite ortamında öğrencilerde ortaya çıkan psiko-sosyal anlamdaki değişimler ile başa çıkılmaya çalışılması sebebiyle zamanı kullanmada sorun yaşamaları düşünülebilir. Öğrencilerin ailelerinden uzaklaşma ve şehir değiştirme durumu öğrencilerde son derece kaygı göstergelerine stres durumlarına yol açabilmektedir. Bu da aynı zamanda kişide motivasyonu engelleyici bir etmen olarak karşımıza çıkar ve zamanını nasıl etkin bir biçimde kullanacağı konusunda bazı problemlere yol açabilmektedir. İkinci sınıf öğrencilerin puanlarının yüksek çıkmasının sebebi olarak ise birinci sınıfta karşılaşmış oldukları birçok zaman yönetim sorunlarıyla ve okul-yaşam yönetim problemleriyle bir sonraki süreçte karşılaşmak istememeleri sebebiyle bir sonraki yıl daha bir disiplin, istikrarlı çalışma gösterdikleri ve işlerini, görevlerini düzenli bir biçimde yerine getirmeye çaba göstermeye çalışmaları gerekçe gösterilebilir.4.sınıf öğrencilerinin zaman yönetim toplam puan ortalamaları diğer sınıf düzeylerinden daha yüksektir. Dördüncü sınıf öğrencilerinin zaman beceri düzeylerinin yüksek çıkması beklenilen bir durumdur. Son sınıf öğrencileri eğitim açısından pedagojik olarak gerekli görülen çoğu dersleri almış, yeterli etkinlikleri yapmış, artık tam manasıyla bir öğretmen profiline bürünmeleri ve sahip oldukları bilincin, sorumlulukların farkında olmaları sebebiyle zamanı etkin kullanabilme becerilerinin gelişmiş olması beklenir. Sınıf yönetimi dersi adı altında zaman yönetimi konusunu işlemesiyle birlikte ders kapsamında gerekli sınıf ve yaşam yönetimi becerileri ve tutumları öğrencilere kazandırılmıştır. Ayrıca son sınıf öğrencilerinin sınav yoğunluklarının azalması, stajda geçirdikleri zamanın artması da zamanın kullanılmasında etkili olmuş olduğu söylenebilir. Tüm bunlara ek olarak son sınıf öğrencilerinin gelecek yaşamlarıyla ilgili gelecek kaygıları oluşturmaları sebebiyle zaman yönetimine daha da hâkim olmaları ve zamanı iyi kullanmaya yönelik çaba göstermeleri beklenir. Buradan yola çıkarak öğrencilerin sınıf seviyeleri arttıkça zaman yönetimi becerileri puanlarının da paralel olarak gelimekte olduğunu söyleyebiliriz.

Tablo 3. Fen Bilimleri Öğretmen Adaylarının Öğrenim Gördükleri Sınıf Düzeyine Göre Zaman Yönetimi Becerilerinin Alt Faktörler Altında İncelenmesi 


\begin{tabular}{ccccc}
\hline SINIF DÜZEYI & & $\begin{array}{c}\text { ZAMAN } \\
\text { PLANLAMA }\end{array}$ & $\begin{array}{c}\text { ZAMAN } \\
\text { TUTUMLARI }\end{array}$ & $\begin{array}{c}\text { ZAMAN } \\
\text { HARCATTIRICILAR }\end{array}$ \\
\cline { 3 - 5 } 1.SINIF & $\mathrm{N}$ & 39 & 39 & 39 \\
& $\mathrm{X}$ & 2,8221 & 3,2454 & 3,3333 \\
& $\mathrm{SS}$ &, 57471 &, 57699 &, 70322 \\
\cline { 2 - 5 } $\mathbf{2 . S I N I F}$ & $\mathrm{N}$ & 31 & 31 & 31 \\
& $\mathrm{X}$ & 3,1028 & 3,4378 & 3,3306 \\
& $\mathrm{SS}$ &, 78868 &, 30625 &, 69338 \\
\cline { 2 - 5 } 3.SINIF & $\mathrm{N}$ & 25 & 25 & 25 \\
& $\mathrm{X}$ & 3,0050 & 3,2457 & 3,4700 \\
& $\mathrm{SS}$ &, 63042 & 49576 &, 68587 \\
\multirow{4}{*}{ 4.SINIF } & $\mathrm{N}$ & 40 & 40 & 40 \\
& $\mathrm{X}$ & 3,1734 & 3,4643 & 3,2250 \\
& $\mathrm{SS}$ &, 54422 &, 40244 &, 75490 \\
\cline { 2 - 5 } TOPLAM & $\mathrm{N}$ & 135 & 135 & 135 \\
& $\mathrm{X}$ & 3,1734 & 3,4643 & 3,2250 \\
& $\mathrm{SS}$ &, 64058 &, 46630 &, 71058 \\
\hline
\end{tabular}

Fen bilimleri öğretmen adaylarının zaman yönetimi becerileri zaman ölçeğinin zaman planlaması, zaman tutumları ve zaman harcattırıcıları faktörleri altında incelenmiştir. Öğrencilerin zaman yönetimi sınıf düzeylerine ilişkin alt faktörlere ilişkin öğrencilerin zaman yönetimi sınıf düzeylerine ilişkin aritmetik ortalama ve standart sapma değerleri Tablo 3'de verilmiştir. Genel olarak öğrencilerin zaman yönetimi algıları toplamda( $=3,17, \mathrm{ss}=, 64)$ "orta" düzeydedir. Zaman Yönetimi ölçeğinin alt boyutlarından Zamanın Planlaması boyutu (=3,2, ss=,64), Zaman Tutumları boyutu $(=3,46, \mathrm{ss}=, 47)$ ve Zaman Harcayıc1lar boyutunda( $=3,22, \mathrm{ss}=, 71)$ alg1ları "orta" düzeydedir. Uygulanılan zaman envanterinden birinci alt ölçekte yüksek puana sahip öğrencilerin doğru olarak planlama yapabilme becerisinde olduğu; İkinci alt ölçekten yüksek puan alan öğrenciler zamanını iyi kullanabilen bireyler olduğu tanımlanması yapılmıştır. Üçüncü alt ölçekten yüksek puana sahip öğrencilerin ileriye dönük amaçlarını oluşturma hususunda başarı göstermiş oldukları düşünülmüştür[20].Dolayısıyla fen bilgisi öğretmen adaylarından elde edilen zaman yönetimi ölçeğine dair faktörlerin puanları hemen hemen aynı kabul edilse de, öğrencilerin zaman tutum becerileri daha yüksektir. Bu durumun tersine zaman planlama becerileri en düşüktür. Elde edilen sonuçları sınıf düzeyi bazında inceleyecek olursak birinci sınıfların ve üçüncü sınıfların en yüksek zaman harcattırıcılar faktörü; ikinci ve dördüncü sınıfların ise zaman tutumları faktörlerinin ortalamalarının en yüksek olduğu anlaşılırken; tüm sınıfların zaman planlama becerilerinin ortalamasının düşük olduğu yönünde olduğu görülür.

\section{Tartışma, Sonuç ve Öneriler}

$\mathrm{Bu}$ araştırma fen bilgisi öğretmen adaylarının zaman yönetimi becerilerinin sınıf düzeyi faktörü açısından belirlenmesi amacıyla gerçekleştirilmiştir. Çalışma gerçekleştirilirken eğitim fakültesinde öğrenim görmekte olan fen bilgisi öğretmen adaylarına zaman yönetimi anketi uygulanmıştır. Uygulama sonrasında yapılan elde edilen veriler arasında sınıflar arasındaki ilişkiyi belirlemek adına ANOVA analizi yapılmış ve elde edilen veriler doğrultusunda fen bilimleri öğretmen adaylarının farklı sınıf düzeyindeki zaman yönetimi becerilerinin gruplar arasında anlamlı bir fark olmadığı belirlenmiştir. $(\mathrm{F}(3,131)=2.213, \mathrm{p}>0.05$.) Sınıflar bazında, tüm fen bilimleri öğretmen adaylarının zaman yönetimi beceri düzeylerinin benzer olduğu sonucuna varılabilir. Elde edilen bu sonucun çalışmaya katılan öğrencilerin yaşlarının birbirine 
çok yakın olmasından kaynaklandığı düşünülmüştür. Bulgular, "Üniversite Öğrencilerinin Zaman Yönetimi Davranışları ve Bu Davranışların Akademik Basarı ile ilişkisi” isimli araştırma ile tutarlılık göstermekte olup araştırmada öğrencilerin zaman yönetimi becerilerinin sınıf değişkenine göre farklılık göstermediği bulunmuştur[21].

Araştırma sonuçlarında fen bilgisi öğretmen adaylarının zaman yönetimi anketinden elde edilen puanlar değerlendirildiğinde fen bilgisi öğretmen adaylarının zaman yönetimi algılarının "yüksek" düzeyde olduğu sonucuna ulaşıldığı söylenebilir. Araştırma sonuçlarında uygulanan zaman yönetimi ölçeğinin alt faktörlerine bakıldığında ölçeğin alt boyutlarından Zamanın Planlaması boyutu $(=3,2$, ss=,64),Zaman Tutumları boyutu $(=3,46, \mathrm{ss}=, 47)$ ve Zaman Harcayıc1lar boyutunda $(=3,22, \mathrm{ss}=, 71)$ öğrencilerin üç alt ölçek bölümünün ortalama puanlarının ve ZYE toplam puanlarının $(3,30)$ orta üstü bir seviyede olması belirli bir düzeyde bir farkındalığa sahip olduklarını göstermektedir. Dolayısıyla da fen bilimleri öğretmen adaylarının zaman yönetim becerileri algılarının "yüksek" düzeyde olduğu sonucuna varılabilir. Literatürde incelendiğinde çalışmamız sonucunda elde ettiğimiz bu bulgu gerçekleştirilen birçok araştırmanın sonucuyla da örtüşme göstermektedir Zaman yönetimiyle ilgili en önemli araştırmalardan biri olan "Üniversite Öğrencilerinin Zaman Yönetimi Becerileri ile Kaygı Düzeyleri Arasındaki İlişki” adlı çalışmada araştırmacı, üniversite öğrencilerinin zaman yönetimi becerilerinin "yüksek" olduğunu saptamış olması araştırmamızın bulgularını birebir destekler niteliktedir[22].İlköğretim okulu öğretmenlerinin zaman yönetimini belirlenmesine yönelik gerçekleştirilen bir araştırmada Fen Bilgisi öğretmenlerinin zaman yönetimi konusunda orta düzeyde oldukları sonucuna ulaşılması çalışmamızın sonucuna paralellik göstermesi bu bulguyu destekler niteliktedir[23].Fen bilimleri öğretmen adaylarının öğrenim gördükleri sınıf düzeyi değişkenine göre zaman yönetim beceri puanları kıyaslandığında dördüncü sınıf öğrencilerinin yönetim becerileri diğer sınıflara göre daha yüksek düzeyde olduğu görülür. En düşük zaman beceri puanına ise birinci sınıfların sahip olduğu görülmektedir. İkinci sınıf öğrencilerinin zaman yönetim puanlarının dördüncü sınıf öğrencileri ile aynı düzeyde olduğu ve diğer üst sınıf kademesinden daha yüksek olduğu göze çarpmaktadır. $\mathrm{Bu}$ durum dışında sınıf düzeyleriyle artış göstermesiyle birlikte zaman becerilerinin artış göstermiş olduğu söylenebilir 4. sınıf öğrencilerinin zaman yönetimi toplam puan ortalamalarının diğer sınıf düzeylerinden daha yüksektir. Literatür incelendiğinde üniversite öğrencilerinin zaman yönetimi becerileri ile akademik başarıları arasındaki ilişkinin belirlenmesine yönelik gerçekleştirilen araştırmada 4. sınıf öğrencilerinin zaman yönetimi toplam puan ortalamalarının diğer sınıf seviyelerinden yüksek çıkmış olması çalışmamızın bulgularıyla örtüşmektedir[24].Bu kapsamda yapılmış olan başka bir çalışmada da sınıf değişkenine göre, son sınıf öğrencilerinin zaman yönetimi becerilerinin, birinci sınıf öğrencilerinden daha yüksek olduğu sonuçlarına varıldığı görülmüştür[25].Öğrencilerin sınıf düzeyleri arttıkça zaman yönetimi becerilerinin de bu doğrultuda gelişim gösterdiğini söylenebilir[26].Elde edilen sonuçlar ve gerçekleştirilen çalışmalar, zaman iyi yönetmede sınıf düzeyinin de etkili bir faktör olduğuna işaret etmektedir. Çeşitli araştırmalar doğrultusunda ulaşılan bulgular çerçevesinde, sınıf düzeyinde zaman algısının da ilerleme kaydettiği aynı zamanda zihinsel gelişim süreciyle paralellik göstermiş olduğu kabul görülmüştür. $\mathrm{Bu}$ doğrultuda üniversite öğrencilerinin almış oldukları eğitim-öğretimin sağlamış olduğu faydalar ile zamanı daha etkin kullanmaya yönelmiş olabildiklerini görmekteyiz. Kısacası zaman yönetimi puanlarının sınıf düzeyiyle orantılıdır, denilebilir. Bu durumdan yola çıkarak öğrencilerin sınıf düzeyleri arttıkça zaman yönetimi becerileri düzeylerinin ise aynı yönde gelişim gösterdiği söylenebilir. Ayrıca geçmişteki aile yaşantısı, eğitim hayatı gibi birçok faktörün etkisiyle zaman yönetim becerisi oluşmuş olabilir. 
Özetle, ilgili alan yazında incelendiğinde etkili zaman yönetimi becerisine sahip olmak öğretmen adayları ve öğretmenler açısından son derece büyük öneme sahip olduğuna işaret etmektedir Literatürde öğretmenlerin zaman yönetimine ilişkin pek çok araştırma gerçekleştirilmiştir. Bir çalışmada beden eğitimi öğretmenlerinin zaman yönetimi becerilerinin incelenmiş[27], başka bir araştırmada Türkçe öğretmenliği öğrencilerinin zaman yönetimine dair algılarının ne yönde olduğu belirlenmiştir[28].Bu amaçla gerçekleştirilen güncel araştırma ise eğitim fakültesi son sınıf öğrencilerinin zaman yönetimi ile stres algıları arasındaki ilişkiyi belirlemeye yönelik yapılmıştır[29].

Sonuç olarak zaman yönetimi becerisi her ne kadar tüm branşlarda öğretmenler için önem arz etse de fen bilimleri dersi öğretmenleri açısından daha da büyük önem arz eder. Fen Bilgisi dersi konuları Laboratuar etkinlikleri veya deneysel çalışmalarla, yaşadığımız çevrede örneklerle zenginleştirilerek anlatılması sebebiyle planlanan sürenin yetersiz gelmesi kaçınılmazdır. Dolayısıyla tüm bunlar fen bilimleri öğretmenlerinin zamanı kullanmada yeterli donanıma sahip olması gerekmesi ve literatürde Fen Bilimleri eğitimcilerine yönelik zaman yönetimi becerisi kapsamında çalışmalarının eksik olması sebebiyle alanyazına katkıda bulunulacağı düşünülerek çalışmada Fen Bilgisi öğretmen adaylarının sahip olduğu zaman yönetimi becerilerinin belirlenmesini amaçlanmıştır. Bu çerçevede zamanın daha iyi kullanılması için öğretmenlere hizmet içi eğitim kursu verilebilir veya öğretmenlerin kullanma konusundaki eksiklikleri giderilmelidir. En önemlisi de zamanın kullanımının daha etkin ve doğru olabilmesi adına öğretmen adaylarına lisans döneminde yeterli eğitimin verilmesi gerekmektedir.

\section{Kaynakça}

[1]Smith, J. (1998). Daha İyi Nasıl Zaman Yönetimi. (Çev. Ali Çimen).İstanbul:Timaş Yayınları. [2]Çelik, V. (2002). Sınıf Yönetimi. Ankara: Nobel Yayıncılık.

[3]WEB_1, (2014), Türk Dil Kurumu, Güncel Türkçe Sözlük

[4]Erdem, R. (1999), “Yöneticiler İçin Zaman Yönetimi”. Modern Hastane Yönetimi, 3(7),26-31.

[5]Akatay, A. (2003). Örgütlerde Zaman Yönetimi, Selçuk Üniversitesi Sosyal Bilimler Enstitütü Dergisi, 10, 282-300.

[6]Efil,İ.(2003). Sınıf Yönetimi.(Ed. L. Küçükahmet). Ankara: Nobel Yayıncılık.

[7]Covey,S.R.(1998) Önemli İşlere Öncelik.(O.Deniztekin,Çev.).İstanbul:Varlık Yayınları

[8]Çam, İ., 2010. "Ortaöğretim Tarih Öğretmenlerinin Derslerinde Zamanı Etkili Kullanma Stratejilerinin Değerlendirilmesi”, Yüksek Lisans Tezi, Çanakkale Onsekiz Mart Üniversitesi Sosyal Bilimler Enstitüsü, Çanakkale.

[9]Pine, K., Messer, D., \& St. John, K. (2001). Children's misconceptions in primary science: A survey of teachers' views. Research in Science \& Technological Education, 19, 79-96.

[10]Aslan, Z ve Doğdu, S. (1993). Eğitim Teknolojisi Uygulamaları ve Eğitim Araç gereçleri. Ankara: Tekışık Ofset.

[11]Hannafin, M.J. \& Rieber, L.P. (1989a). Psychological foundations of instructional design for emerging computer-based instructional technologies: Part I. Educational Technology Research and Development 37: 91-101.

[12]Uyduran, İ. M. (2014). İlkokul Yöneticilerinde Zaman Yönetimi. Yayınlanmamış Yüksek Lisans Tezi, Okan Üniversitesi, İstanbul

[13]Küçük, M. (2014). Ortaöğretim Kurumu Yöneticilerinin Zaman Yönetimi Becerileri İle Tutumları(Adıyaman İli Örneği)Yayınlanmamış Yüksek Lisans Tezi, Türk Hava Kurumu Üniversitesi, Sosyal Bilimler Enstitüsü, 
[14]Türe G. Hazırlık Okulu öğrencilerinin Zaman Yönetimi Becerileri ile Stres Yönetimi Becerileri Arasındaki İlişkinin Araştırılması: Yeditepe Üniversitesi örneği. Yeditepe Üniversitesi Sosyal Bilimler Enstitüsü Bilim Uzmanlığı Tezi. 2013.

[15]Hacıbalayeva, A. (2017).Lisansüstü öğrencilerinin zaman yönetimi becerilerinin incelenmesi: Ondokuz Mayıs Üniversitesi ve Azerbaycan Devlet İktisat Üniversitesi karşılaştırması. Yayınlanmamış Yüksek Lisans Tezi. Ondokuz Mayıs Üniversitesi, Sosyal Bilimler Enstitüsü, Samsun [16]Frankel, J., \& Wallen, T. (2006). Cross-cultural on Organizational Commitment: A Further Review and Application of Hofstede's Value Survey Module. Journal of International Business and Entrepreneurship. 10,1, 1-26.

[17]Karasar, N. (2012). Bilimsel Araştırma Yöntemi (24.baskı). Ankara: Nobel Yayıncılık. [18]Fraenkel, J. R., Wallen, N. E., \& Hyun, H. H. (2012). How To Design and Evaluate Research In EducatIon (8th ed.). New York: Mc Graw HIll.

[19]Britton, B. K., \& Tesser, A. (1991). Effects of Time Management Practices on College Grades. Journal of Educational Psychology, 83, 405-410.

[20]Alay, S. \& Koçak, S. (2002) Validity and Reliability of Time Management Questionnaire. Hacettepe Üniversitesi Egitim Fakültesi Dergisi, 22, 9-13.

[21]Dikmetaş, E.,Erdem R. ve Pirinçci,E. (2004).Üniversite Öğrencilerinin Zaman Yönetimi Davranışları ve Bu Davranışların Akademik Başarı ile İlişsisi, Manas Üniversitesi Sosyal Bilimler Dergisi.

[22]Erdul, G. (2005). Üniversite Öğrencilerinin Zaman Yönetimi Becerileri ile Kayg1 Düzeyleri Arasındaki İlişki. (Yayınlanmamış Yüksek Lisans Tezi). Uludağ Üniversitesi, Bursa.

[23]Gözel, E. (2009). ̇̇lköğretim Okulu Öğretmenlerinin Zaman Yönetimi Hakkındaki Görüşleri. Yayımlanmamış Yüksek Lisans Tezi, Afyon Kocatepe Üniversitesi Sosyal Bilimler Enstitüsü, Afyonkarahisar

[24]Andiç, H. (2009). Üniversite öğrencilerinin zaman yönetimi becerileri ile akademik başarıları arasındaki ilişki. Yayınlanmamış Yüksek Lisans Tezi. Afyon Kocatepe Üniversitesi Sosyal Bilimler Enstitüsü, Afyon.

[25]Bay, E., Gençdoğan, B., Tuğluk, M.N. (2005). Üniversite Öğrencilerinin Ders Çalışma Becerilerinin İncelenmesi.(Kazım Karabekir Eğitim Fakültesi Örneği) Elektronik Sosyal Bilimler Dergisi.

[26]Sezen, A. (2013). İlahiyat Fakültesi Öğrencilerinin Zaman Yönetimi Becerilerinin İncelenmesi. Akademik Bakış Dergisi, Uluslararası Hakemli Sosyal Bilimler E-Dergisi, 38, 1-18 [27]Caz,Ç.,Tunçkol, H.M., 2015.“Beden Eğitimi Öğretmenlerinin Zaman Yönetimi Becerilerinin İncelenmesi

[28]Varışoğlu, S. \& Yılmaz (2012). Türkçe öğretmeni adaylarının zaman yönetimi becerileri ve tutumlarının incelenmesi, A. Ü. Türkiyat araştırmaları enstitüsü dergisi, 47, 75-86.

[29]Yıldız, K . (2018). Eğitim Fakültesi Öğrencilerinin Zaman Yönetimi ve Stres Algılarının İncelenmesi. Sakarya University Journal of Education, 8 (3), 80-99. 